\title{
Sejarah Perkembangan Peradilan Agama pada Masa Kesultanan dan Penjajahan Sampai Kemerdekaan
}

\author{
Miftakhur Ridlo \\ Institut Agama Islam Uluwiyah Mojokerto \\ rheydlo@yahoo.co.id
}

\begin{abstract}
Religious courts in the form they are known today are an unbroken link in the history of the entry of Islam. To give an idea of the position of the Religious Courts in Indonesia, it is necessary to pay attention to Islamic law in Indonesia, at least in three important periods: the pre-colonial period, namely the Islamic Sultanate period, the colonial period and the independence period. Each era has its own characteristics that represent the ebb and flow of Islamic legal thought in Indonesia.
\end{abstract}

Keyword: Judicature, Development History, Indonesia

\begin{abstract}
Abstrak
Peradilan agama dalam bentuk yang dikenal sekarang ini merupakan mata rantai yang tidak terputus dari sejarah masuknya agama Islam. Untuk memberi gambaran tentang posisi lembaga Peradilan Agama di Indonesia haruslah memperhatikan Hukum Islam di Indonesia, sedikitnya pada tiga masa penting: masa sebelum penjajahan yakni masa Kesultanan Islam, masa Penjajahan dan masa Kemerdekaan. Setiap masa mempunyai ciriciri tersendiri yang merepresentasikan pasang surut pemikiran hukum Islam di Indonesia.
\end{abstract}

Kata Kunci: Peradilan, Sejarah Perkembangan, Indonesia

\section{A. PENDAhuluan}

Membicarakan sejarah peradilan Agama di Indonesia erat hubungannya dengan hukum Islam dan umat Islam di Indonesia. Peradilan Agama didasarkan pada hukum Islam, sedangkan dalam perkembangannya hukum Islam merupakan hukum yang berdiri sendiri dan telah lama dianut oleh pemeluk agama Islam di Indonesia. Di kerajaankerajaan Islam masa lampau, hukum Islam telah berlaku. Snouck Hurgronje misalnya, di dalam bukunya De Islam in Nederlansch-Indie mengakui bahwa pada abad ke-16 sudah muncul kerajaan-kerajaan Islam seperti Mataram, Banten, dan Cirebon, yang berangsurangsur mengislamkan penduduknya. Sedangkan untuk kelengkapan pelaksanaan hukum Islam, didirikan Peradilan Serambi dan Majelis Syara'. 
Peradilan Islam di Indonesia yang selanjutnya disebut dengan peradilan agama telah ada di berbagai nusantara jauh sejak zaman masa penjajahan Belanda. Bahkan menurut pakar sejarah peradilan, peradilan agama sudah ada sejak Islam masuk ke Indonesia, yaitu melalui tahkim, dan akhirnya pasang surut perkembanganya hingga sekarang. Peradilan agama sebagai wujud peradilan Islam di Indonesia dapat dilihat dari berbagai sudut pandang. Pertama, secara filosofis peradilan dibentuk dan dikembangkan untuk menegakkan hukum dan keadilan; Kedua, secara yuridis hukum Islam (di bidang perkawinan, kewarisan, wasiat, hibah, wakaf dan sodaqoh) berlaku dalam pengadilan dalam lingkungan peradilan agama; Ketiga, secara historis peradilan agama merupakan salah satu mata rantai peradilan agama yang berkesinambungan sejak masa Rasulullah; Keempat, secara sosiologis peradilan agama didukung dan dikembangkan oleh masyarakat Islam.

Meskipun praktik diskriminasi terhadap pribumi tetap berlangsung dan pendangkalan terhadap Peradilan Agama melalui berbagai ketentuaan hukum yang diciptakan terus dilakukan, eksistensi peradilaan agama tetap kokoh. Tapi walau bagaimanapun juga kalau dibiarkan terus menerus seperti itu, peradilan agama di Indonesia akan tersisihkan dan akhirnya hilang. Oleh karena itu pada kesempatan ini kami akan mencoba mengulas sedikit tentang sejarah peradilan agama di Indonesia yang meliputi perkembangan peradilan di Indonesia masa Kesultanan Islam, masa penjajahan Jepang dan Belanda, hingga Masa Kemerdekaan.

\section{B. PEMBAHASAN}

\section{Sejarah Perkembangan Pengadilan Agama Di Indonesia.}

Peradilan agama dalam bentuk yang dikenal sekarang ini merupakan mata rantai yang tidak terputus dari sejarah masuknya agama Islam. Untuk memberi gambaran tentang posisi lembaga Peradilan Agama di Indonesia haruslah memperhatikan Hukum Islam di Indonesia, sedikitnya pada tiga masa penting: masa sebelum penjajahan yakni masa Kesultanan Islam, masa Penjajahan dan masa Kemerdekaan. Setiap masa mempunyai ciriciri tersendiri yang merepresentasikan pasang surut pemikiran hukum Islam di Indonesia. 
Pada bagian ini akan ditunjukan peradilan masa kesultanan Islam, disusul uraian masa kolonial serta masa kemerdekaan. ${ }^{1}$

\section{a. Peradilan Agama pada masa Kesultanan Islam}

Pertumbuhan dan perkembangan Peradilan Agama pada masa kesultanan Islam bercorak majemuk. Kemajemukan itu sangat bergantung kepada proses Islamisasi yang dilakukan oleh pejabat agama dan ulama dari kalangan pesantren; dan bentuk integrasi antara hukum Islam dengan kaidah lokal yang hidup dan berkembang sebelumnya. Kemajemukan peradilan itu terletak pada otonomi dan perkembangannya, yang berada dalam lingkungan kesultanan masing-masing. Selain itu, terlihat dalam susunan pengadilan dan hierarkinya, kekuasaan pengadilan dalam kaitannya dengan kekuasaan pemerintahan secara umum, dan sumber pengambilan hukum dalam penerimaan dan penyelesaian perkara yang diajukan kepadanya. ${ }^{2}$

Sebenarnya sebelum Islam datang ke Indonesia, di negeri ini telah dijumpai dua macam peradilan, yakni Peradilan Pradata dan Peradilan Padu. ${ }^{3}$ Peradilan Pradata mengurus masalah-masalah perkara yang menjadi urusan raja sedangkan Peradilan Padu mengurus masalah yang tidak menjadi wewenang raja. Pengadilan pradata apabila diperhatikan dari segi materi hukumnya bersumber hukum Hindu yang terdapat dalam papakem atau kitab hukum sehingga menjadi hukum tertulis, sementara Pengadilan Padu berdasarkan pada hukum Indonesia asli yang tidak tertulis.

Menurut R. Tresna (1977:17), dengan masuknya agama Islam di Indonesia, maka tata hukum di Indonesia mengalami perubahan. Hukum Islam tidak hanya menggantikan hukum Hindu, yang berwujud dalam hukum pradata, tetapi juga memasukkan pengaruhnya dalam berbagai aspek kehidupan masyarakat pada umumnya. Meskipun hukum asli masih menunjukan keberadaannya, tetapi hukum Islam telah merembes di kalangan para penganutnya terutama hukum keluarga. ${ }^{4}$

Bersamaan perkembangan masyarakat Islam, ketika Indonesia terdiri dari sejumlah kerajaan Islam, maka dengan penerimaan Islam dalam kerajaan, otomatis para hakim yang

\footnotetext{
${ }^{1}$ Abdul Halim, Peradilan Agama Dalam Politik Hukum Islam (Jakarta: PT. Raja Grafindo Persada, 2000), Hal: 33-34.

${ }^{2}$ Cik Hasan Bisri, MS., Peradilan Agama Di Indonesia (Jakarta: PT. Raja Grafindo Persada, 2003), Cet: 4, Hal: 113.

${ }^{3}$ Abdul Halim, Op. Cit.,Hal: 34.

${ }^{4}$ Cik Hasan Bisri, MS., Op. Cit., Hal: 113.
} 
melaksanakan keadilan diangkat oleh sultan atau imam. Berikut akan dijelaskan sejarah peradilan pada masing-masing kerajaan di Indonesia. ${ }^{5}$

\section{b. Peradilan Agama Islam di kerajaan Mataram}

Kerajaan Islam yang paling penting dijawa adalah Demak (yang kemudian diganti oleh Mataram), Cirebon dan Banten. Di Indonesia timur yang paling penting adalah Goa di Sulawesi Selatan dan Ternate yang pengaruhnya luas hingga kepulauan Filipina, di Sumatra yang paling penting adalah Aceh yang wilayahnya meliputi wilayah Melayu. Keadaan terpencar kerajaan-kerajaan Indonesia dan hubungannya dengan negara-negara tetangga, Malaysia dan Filipina. ${ }^{6}$

Dengan munculnya Mataram menjadi kerajaan Islam, dibawah pemerintahan Sultan Agung mulai diadakan perubahan dalam sistem peradilan dengan memasukkan unsur hukum dan ajaran agama Islam dengan cara memasukkan orang-orang Islam kedalam Peradilan Peradaban. Namun, setelah kondisi masyarakat dipandang siap dan paham dengan kebijakan yang diambil sultan agung, maka kemudian peradilan pradata yang ada diubah menjadi Peradilan Serambi dan lembaga ini tidak secara langsung berada dibawah raja, tetapi dipimpin oleh ulama. Ketua pengadilan meskipun pada prinsipnya ditangan sultan, tetapi dalam pelaksanaannya berada ditangan penghulu yang didampingi beberapa orang ulama dari lingkungan pesantren sebagai anggota majelis. Sultan tidak pernah mengambil keputusan yang bertentangan dengan nasihat Peradilan Serambi. Meski terjadi perubahan nama dari Pengadilan Pradata menjadi Pengadilan Serambi, namun wewenang kekuasaannya masih tetap seperti peradilan pradata.

Ketika Amangkurat I menggantikan Sultan Agung pada tahun 1645, peradilan perdata dihidupkan kembali untuk mengurangi pengaruh ulama dalam pengadilan dan raja sendiri yang menjadi tampuk kepimpinannya. Namun dalam perkembangan berikutnya pengadilan serambi masih menunjukkan keberadaannya sampai pada masa penjajahan Belanda, meskipun dengan kewenangan yang terbatas menurut Snouck (1973:21) pengadilan tersebut berwenang menyelesaikan perselisihan dan persengketaan yang berhubungan dengan hukum kekeluargaan, yaitu perkawinan dan kewarisan. ${ }^{7}$

\section{c. Peradilan Islam di Kerajaan Aceh}

\footnotetext{
${ }^{5}$ Abdul Halim, Op. Cit., Hal: 38.

${ }^{6}$ Ibid., Hal: 38-39.

${ }^{7}$ Cik Hasan Bisri, MS., Op. Cit., Hal: 114.
} 
Di Aceh, sistem peradilan yang berdasarkan hukum Islam menyatu dengan pengadilan negeri, yang mempunyai tingkatan-tingkatan;

1) Dilaksanakan ditingkat kampung yang dipimpin Keucik. Peradilan ini hanya menangani perkara-perkara yang tergolong ringan. Sedangkan perkara-perkara berat diselesaikan oleh Balai Hukum Mukim.

2) Apabila yang berperkara tidak puas dengan keputusan tingkat pertama, dapat mengajukan banding ke tingkat yang ke dua yakni Oeloebalang.

3) Bila pada tingkat Oeloebalang juga dianggap tidak dapat memenuhi keinginan pencari keadilan, dapat mengajukan banding ke pengadilan tingkat ke tiga yang disebut Panglima Sagi.

4) Seandainya keputusan Panglima Sagi tidak memuaskan masih dapat mengajukan banding kepada Sultan yang pelaksanaannya oleh Mahkamah agung yang terdiri anggotanya Malikul Adil, orang kaya sri paduka tuan, orang kaya raja bandara, dan fakih (ulama). Sistem peradilan di Aceh sangat jelas menunjukkan hirarki dan kekuasaan absolutnya. ${ }^{8}$

\section{d. Peradilan agama Islam di Periangan}

Di Cirebon atau Periangan terdapat tiga bentuk peradilan; Peradilan Agama, Peradilan Drigama, dan Peradilan Cilaga. Kompetensi Peradilan Agama adalah perkaraperkara yang dapat dijatuhi hukuman badan atau hukum mati, yaitu yang menjadi absolut kompetensi peradilan pradata di Mataram. Perkara-perkara tidak lagi dikirim ke Mataram, karena belakangan kekuasaan pemerintah Mataram telah merosot. Kewenangan absolut Peradilan Drigama adalah perkara-perkara perkawinan dan waris. Sedangkan Peradilan Cilaga khusus menangani sengketa perniagaan. Pengadilan ini dikenal dengan pengadilan wasit. ${ }^{9}$

\section{e. Peradilan Agama Islam di Banten}

Sementara itu di Banten pengadilan disusun menurut pengertian Islam. Pada masa sultan Hasanuddin memegang kekuasaan, pengaruh hukum Hindu sudah tidak berbekas lagi. Karena di Banten hanya ada satu pengadilan yang dipimpin oleh Qodli sebagai hakim tunggal. lain halnya dengan Cirebon yang pengadilannya dilaksanakan oleh tujuh orang menteri yang mewakili tiga sultan yaitu Sultan Sepuh, Sultan Anom dan Panembahan Cirebon. Kitab hukum yang digunakan adalah pepakem Cirebon yang merupakan

\footnotetext{
${ }^{8}$ Ibid., Hal: 115.

${ }^{9}$ Abdul Halim, Op. Cit., Hal: 43.
} 
kumpulan macam-macam Hukum Jawa Kuno memuat Kitab Hukum Raja Niscaya, Undang-Undang Mataram, Jaya Lengkara, Kontra Menawa dan Adidullah. Namun satu hal yang tidak dipungkiri bahwa pepakem Cirebon tanpa adanya pengaruh hukum Islam. ${ }^{10}$

\section{f. Peradilan Agama Islam di Sulawesi}

Di Sulawesi integrasi ajaran Islam dan lembaga-lembaganya dalam pemerintahan kerajaan dan adat lebih lancar karena peranan raja. Di Sulawesi, kerajaan yang mula-mula menerima Islam dengan resmi adalah kerajaan Tallo di Sulawesi Selatan. Kemudian disusul oleh kerjaan Goa yang merupakan kerajaan terkuat dan mempunyai pengaruh dikalangan masyarakatnya.

Sementara itu di beberapa wilayah lain; seperti Kalimantan Selatan dan Timur, dan tempat-tempat lain, para hakim agama di angkat sebagai penguasa setempat. ${ }^{11}$

Dengan berbagai ragam pengadilan itu, menunjukan posisinya yang sama yaitu sebagai salah satu pelaksana kekuasaan raja atau sultan. Di samping itu pada dasarnya batasan wewenang Pengadilan Agama meliputi bidang hukum keluarga, yaitu perkawinan dan kewarisan. Dengan wewenang demikian, proses pertumbuhan dan perkembangan pengadilan pada berbagai kesultanan memiliki keunikan masing-masing. Dan fungsi sultan pada saat itu adalah sebagai pendamai apabila terjadi perselisihan hukum.

\section{Peradilan Agama Pada Masa Kolonial Belanda}

Masyarakat pada masa itu dengan rela dan patuh serta tunduk mengikuti ajaranajaran Islam dalam berbagai dimensi kehidupan. Namun, keadaan itu kemudian menjadi terganggu dengan munculnya kolonialisme barat yang membawa misi tertentu, mulai dari misi dagang, politik bahkan sampai misi kristenisasi. ${ }^{12}$

Sejak tahun 1800, para ahli hukum dan ahli kebudayaan Belanda mengakui bahwa dikalangan masyarakat Indonesia Islam merupakan agama yang sangat dijunjung tinggi oleh pemeluknya. Penyelesaian masalah kemasyarakatan senantiasa merujuk kepada ajaran agama Islam, baik itu soal ibadah, politik, ekonomi dan kemasyarakatan lainnya. Atas fenomena ini, maka para pakar hukum Belanda berkeyakinan bahwa ditengah-tengah komunitas itu berlaku hukum Islam, termasuk dalam mengurus peradilan pun diberlakukan undang-undang agama Islam.

\footnotetext{
${ }^{10}$ Cik Hasan Bisri, MS., Op. Cit., Hal: 115.

${ }^{11}$ Abdul Halim, Op. Cit., Hal: 45.

${ }^{12}$ Abdul Halim, Op. Cit., Hal: 46.
} 
Bukti Hindia Belanda secara tegas mengakui bahwa UU Islam (hukum Islam) berlaku bagi orang Indonesia yang bergama Islam. Pengakuan ini tertuang dalam peraturan perundang-undangan tertulis pada 78 reglement op de beliedder regeerings van nederlandsch indie disingkat dengan regeerings reglement (RR) staatsblad tahun 1854 No. 129 dan staatsblad tahun 1855 No. 2. Peraturan ini mengakui bahwa telah diberlakukan undang-undang agama (godsdienstige wetten) dan kebiasaan penduduk Indonesia.

Pasal 78 RR berbunyi: "dalam hal terjadi perkara perdata antara sesama orang Indonesia asli atau dengan orang yang dipersamakan dengan mereka, maka mereka tunduk pada putusan hakim agama atau kepada masyarakat mereka menurut UU agama atau ketentuan-ketentuan lama mereka". ${ }^{13}$

Beberapa macam peradilan menurut Supomo (1970:20) pada masa penjajahan Belanda terdapat lima buah tatanan peradilan. ${ }^{14}$

a. Peradilan Gubernemen, tersebar diseluruh daerah Hindia Belanda.

b. Peradilan Pribumi tersebar di luar Jawa dan Madura, yaitu di karesidenan Aceh, Tapanuli, Sumatera Barat, Jambi, Palembang, Bengkulu, Riau, Kalimantan Barat, Kalimantan Selatan dan Timur, Manado, dan Sulawesi, Maluku dan di Pulau Lombok dari karesidenan Bali dan Lombok.

c. Peradilan Swapraja, tersebar hampir diseluruh daerah Swapraja kecuali di Pakualaman dan Pontianak.

d. Peradilan Agama tersebar di daerah-daerah tempat kedudukan peradilan Gubernemen, di daerah-daerah dan menjadi bagian dari bagian Peradilan Pribumi, atau di daerahdaerah Swapraja dan menjadi bagian dari Peradilan Swapraja.

e. Peradilan Desa tersebar di daerah-daerah tempat berkedudukan peradilan Gubernemen. Disamping itu ada juga peradilan desa yang merupakan bagian dari Peradilan Pribumi Atau Peradilan Swapraja.

Pada mulanya pemerintah Belanda tidak mau mencampuri organisasi pengadilan agama, tetapi pada tahun 1882 dikeluarkan penetapan raja Belanda yang dimuat dalam staatsblad 1882 no.152. dengan adanya ketetapan tersebut terdapat perubahan yang cukup penting, ${ }^{15}$ Yaitu :

\footnotetext{
${ }^{13}$ Abdullah Tri Wahyudi, Peradilan Agama Di indonsia, (Yogyakarta: Pustaka Pelajar, 2004), Hal: 8.

${ }^{14}$ Cik Hasan Bisri, MS., Op. Cit., Hal: 116-117.

${ }^{15}$ Ibid., Hal: 117.
} 
a. Reorganisasi ini pada dasarnya membentuk Pengadilan Agama yang baru disamping Landraad dengan wilayah hukum yang sama, yaitu rata-rata seluas daerah kabupaten.

b. Pengadilan itu menetapkan perkara-perkara yang dipandang masuk dalam lingkungan kekuasaan. Menurut Noto Susanto (1963:7) perkara-perkara itu umumnya meliputi: pernikahan, segala jenis perceraian, mahar, nafkah, keabsahan anak, perwalian, kewarisan, hibah, waqaf, shadaqah, dan baitul mal, yang semuanya erat dengan agama Islam.

Pemerintah Belanda dengan tegas membentuk peradilan agama berdasarkan Staatsblad tahun 1882 no. 152 tentang pembentukan Peradilan Agama di Jawa-Madura. Pengakuan hukum Islam yang berlaku bagi orang Indonesia pada waktu itu menurut penulis Belanda Van De Berg mengemukakan sebuah teori yang disebut teori receptio in complexu yang artinya bagi orang Islam berlaku hukum Islam walaupun terdapat penyimpangan-penyimpangan.

Teori receptio in complexu yang dikemukakan Van De Berg mendapat kritikan tajam oleh Snouck Hurgronje karena teori receptio in complexu bertentangan dengan kepentinggan-kepentingan pemerintah Hindia Belanda dan akhirnya mengemukakan teori receptio yang menurut teori ini hukum yang berlaku di Indonesia adalah hukum adat asli. Hukum Islam baru mempunyai kekuatan kalau dikehendaki dan diterima oleh hukum adat.

Teori receptio bertujuan untuk mengetahui peranan hukum Islam dengan mengedepankan hukum adat atau bahkan mengganti hukum Islam dengan hukum adat. Selain itu bertujuan untuk memperkuat pemerintah kolonial dan adanya kepentingan pemerintah kolonial dalam penyebaran agama Kristen di wilayah Hindia Belanda.

Kekuasaan dan kewenangan peradilan agama di Jawa-Madura meliputi: ${ }^{16}$

a. Perselisihan antara suami istri yang bergama Islam.

b. Perkara-perkara tentang: nikah, talak, rujuk, dan perceraian antara orang-orang yang beragama Islam.

c. Menyelenggarakan perceraian.

d. Menyatakan bahwa syarat untuk jatuhnya talak yang digantungkan (ta'liq al-thalaq) telah ada.

e. Perkara mahar atau maskawin.

f. Perkara nafkah wajib suami kepada istri.

\footnotetext{
${ }^{16}$ Abdullah Tri Wahyudi, Op. Cit., Hal: 10-11.
} 
Pemberlakuan peraturan pemerintah tersebut pada kenyataannya tidak memberikan jalan keluar bagi peradilan agama di daerah lainnya. Karena itu pemerintah pada tahun yang sama mencabutnya kembali dan menerbitkan peraturan yang lain yaitu peraturan pemerintah no. 45 tahun 1957 tentang pendirian mahkamah syari'ah di luar Jawa dan Madura. Dalam peraturan ini disebutkan tentang wewenang absolut Peradilan Agama. Menurut peraturan itu, wewenang mahkamah syari'ah adalah:
a. Nikah
b. Talak
c. Rujuk
d. Fasakh
e. Nafaqah
f. Mahar
g. Tempat kediaman
h. Mut'ah
i. Hadlanah
j. Perkara waris-mewaris
k. Wakaf
1. Hibah
m. Shadaqah
n. Baitul mal

Pada periode tahun 1882 sampai dengan 1937 secara yuridis formal, peradilan agama sebagai suatu badan peradilan yang terkait dalam sistem kenegaraan untuk pertama kali lahir di Indonesia (Jawa dan Madura) pada tanggal 11 agustus 1882 kelahiran ini berdasarakan suatu keputusan raja Belanda (konnink besluit) yakni raja Willem III tanggal 19 januari 1882 no. 24 yang dimuat dalam staatsblad 1882 no. 152. Badan peradilan ini bernama Priesterraden yang kemudian lazim disebut dengan rapat agama atau Raad Agama dan terakhir dengan pengadilan agama.

Keputusan raja Belanda ini dinyatakan berlaku mulai 1 Agustus 1882 yang dimuat dalam Staatblad 1882 no.153, sehingga dengan demikian dapatlah dikatakan tanggal kelahiran badan peradilan agama di Indonesia adalah 1 agustus $1882 .{ }^{17}$

Staatblad 1882 no.152 berisi tujuh pasal yang maksudnya adalah sebagai berikut:

\footnotetext{
${ }^{17}$ Abdul Halim, Op. Cit., Hal: 51.
} 
Pasal 1

Di samping setiap landraad (pengadilan negeri) di Jawa dan Madura diadakan satu pengadilan agama, yang wilayah hukumnya sama dengan wilayah hukum landraad.

Pasal 2

Pengadilan agama terdiri atas; penghulu yang diperbantukan kepada landraad sebagai ketua. Sekurang-kurangnya tiga dan sebanyak-banyaknya delapan orang ulama Islam sebagai anggota. Mereka diangkat dan diberhentikan oleh gubernur / residen.

Pasal 3

Pengadilan agama tidak boleh menjatuhkan putusan, kecuali dihadiri oleh sekurangkurangnya tiga anggota termasuk ketua. Kalau suara sama banyak, maka suara ketua yang menentukan.

Pasal 4

Putusan pengadilan agama dituliskan disertai dengan alasan-alasannya yang singkat, juga harus diberi tanggal dan ditandatangani oleh para anggota yang turut memberi keputusan. Dalam berperkara itu disebutkan pula ongkos yang dibebankan kepada pihak-pihak yang berperkara.

Pasal 5

Kepada pihak-pihak yang berperkara harus diberikan salinan surat keputusan yang ditandatangani oleh ketua.

Pasal 6

Keputusan pengadilan agama harus dimuat dalam suatu daftar dan harus diserahkan kepada residen setiap tiga bulan sekali untuk memperoleh penyaksian (visum) dan pengukuhan.

Pasal 7

Keputusan pengadilan agama yang melampaui batas wewenang atau kekuasaannya atau tidak memenuhi ketentuan ayat (2), (3), dan (4) tidak dapat dinyatakan berlaku.

\section{Peradilan Agama Pada Masa Kolonial Jepang}

Tahun 1942 adalah tahun Indonesia diduduki oleh Jepang. Kebijaksanaan pertama yang dilakukan oleh Jepang terhadap perundang-undangan dan pengadilan ialah bahwa semua peraturan perundang-undangan yang berasal dari pemerintahan Belanda dinyatakan tetap berlaku sepanjang tidak bertentangan. Peradilan Agama tetap dipertahankan dan tidak mengalami perubahan, peradilan agama dan Kaikiooo Kottoo Hooin untuk 
Mahkamah Islam Tertinggi, berdasarkan aturan peralihan pasal 3 bala Jepang (Osanu Seizu) tanggal 07 maret 1942 No.1. ${ }^{18}$

Pada zaman Jepang, posisi pengadilan agama tetap tidak akan berubah kecuali terdapat perubahan nama menjadi Sooryo Hooin. Pemberian nama baru itu didasarkan pada aturan peralihan pasal 3 Олапи Seizu tanggal 7 maret 1942 No. 1. Pada tanggal 29 April 1942, pemerintah balatentara Dai Nippon mengeluarkan UU No. 14 tahun 1942 yang berisi pembentukan Gunsei Hoiin (pengadilan pemerintah balatentara). Dalam pasal 3 UU ini disebutkan bahwa Gunsei Hooin terdiri dari: ${ }^{19}$
a. Tiho hooin (pengadilan negeri)
b. Keizai hooin (hakim poloso)
c. Ken hooin (pengadilan kabupaten)
d. Kaikioo kootoo hoin (mahkamah Islam tinggi)
e. Sooryoo hoon (raad agama)

Kebijaksanaan kedua yang dilakukan oleh pemerintahan Jepang adalah, pada tanggal 29 april 1942 pemerintahan bala tentara Dai Nippon mengeluarkan UU No. 14 tahun 1942 tentang pengadilan bala tentara Dai Nippon. Dalam pasal 1 disebutkan bahwa di tanah Jawa dan Madura telah diadakan "gunsei hooin" (pengadilan pemerintahan balatentara). ${ }^{20}$

Pada masa pendudukan Jepang kedudukan pengadilan agama pernah terancam yaitu tatkala pada akhir Januari 1945 pemerintah bala tentara Jepang (guiseikanbu) mengajukan pertanyaan pada Dewan Pertimbangan Agung (Sanyo-Aanyo Kaigi Jimushitsu) dalam rangka Jepang akan memberikan kemerdekaan pada bangsa Indonesia yaitu bagaimana sikap dewan ini terhadap susunan penghulu dan cara mengurus kas masjid, dalam hubungannya dengan kedudukan agama dalam negara Indonesia merdeka kelak.

Akan tetapi dengan menyerahnya Jepang dan Indonesia memproklamirkan kemerdekaan pada tanggal 17 agustus 1945, maka dewan pertimbangan agung buatan Jepang itu mati sebelum lahir dan peradilan agama tetap eksis di samping peradilanperadilan yang lain.

\footnotetext{
${ }^{18}$ Basiq Jalil, peradilan agama di Indonesia (Jakarta: Prenada Media Group, 2006), hal: 60

${ }_{19}^{19}$ Achmad Gunaryo, Pergumulan Politik Dan Hukum Islam (Yogyakarta: Pustaka Pelajar), hal: 96.

${ }^{20}$ Basic Jalil, Op. Cit., Hal: 60.
} 


\section{Peradilan Agama pada Masa Kemerdekaan \\ a. Pada Masa Awal Kemerdekaan}

Pada awal kemerdekaan republik Indonesia pengadilan agama masih berpedoman kepada peraturan perundangan-undangan pemerintah kolonial Belanda berdasarkan pasal II aturan peralihan UUD 1945 yang berbunyi: "segala badan selama belum diadakan yang baru menurut UUD ini”

Peranan peradilan agama sebagai pelaksana kekuasaan kehakiman yang mandiri dihapuskan. Peradilan agama menjadi bagian dari Peradilan Umum. Untuk menangani perkara yang menjadi kewenangan dan kekuasaan peradilan agama ditangani oleh peradilan umum secara istimewa dengan seorang hakim yang beragama Islam sebagai ketua dan didampingi dua orang hakim ahli agama Islam

Pada masa berikutnya, berdasarakan ketentuan pasal 98 UUD sementara dan pasal 1 ayat (4) UU darurat no. 1 tahun 1951, pemerintah mengeluarkan PP No. 45 tahun 1957 tentang pembentukan Pengadilan Agama atau Mahkamah Syar'iyah di luar Jawa-Madura. Menurut ketentuan pasal 1, "di tempat-tempat yang ada pengadilan negeri ada sebuah Pengadilan Agama atau Mahkamah Syar'iyah, yang daerah hukum sama dengan daerah hukum pengadilan negeri”. Sedangkan menurut ketentuan pasal 11, "apabila tidak ada ketentuan lain, di ibu kota propinsi diadakan Pengadilan Agama atau Mahkamah Syar'iyah propinsi yang wilayahnya meliputi satu, atau lebih, daerah, propinsi yang ditetapkan oleh menteri agama. $^{21}$

Adapun kekuasaan Pengadilan Agama atau Mahkamah Syar'iyah itu, menurut ketetapan pasal 4 PP tersebut, adalah sebagai berikut:

1) Pengadilan Agama / Mahkamah Syar'iyah memeriksa atau memutuskan perselisihan antara suami dan istri yang beragama Islam dan semua perkara yang menurut hukum yang diputus menurut hukum agama Islam yang berkenaan dengan nikah, thalaq, ruju', fasakh, nafaqah, maskawin (mahr), tempat kediaman, muth'ah dan sebagainya

2) Pengadilan Agama atau Mahkamah Syar'iyah tidak berhak memeriksa perkaraperkara tersebut dalam ayat (1) jika untuk perkara itu berlaku lain daripada hukum agama Islam.

\footnotetext{
${ }^{21}$ Cik Hasan Bisri, MS., Op. Cit., Hal: 123.
} 


\section{b. Masa Orde Baru}

Uraian di atas menunjukkan bahwa sekitar 25 tahun sejak kemerdekaan terdapat keanekaragaman dasar penyelenggraan, kedudukan, susunan, dan kekuasaan pengadilan dalam lingkungan PADI. Selanjutnya, pada tahun 1970 Jo. UU no. 35 tahun 1999, dan UU no. 1 tahun 1974 serta peraturan pelaksanaannya. Dengan berlakunya UU No. 14 tahun 1970 Jo. UU No. 35 tahun 1999 memberi tempat kepada PADI sebagai salah satu peradilan dalam tata peradilan di Indonesia yang melaksanakan kekuasaan kehakiman dalam negara kesatuan republik Indonesia. Dengan berlakunya UU No. 1 tahun 1974, maka kekuasaan pengadilan dalam lingkungan PADI bertambah. Oleh karena itu, maka tugas-tugas badan peradilan agama menjadi meningkat,. "dari rata-rata 35.000 perkara sebelum berlakunya UU perkawinan menjadi hampir 300.000-an perkara" dalam satu tahun di seluruh Indonesia. Dengan sendirinya hal itu mendorong usaha meningkatkan jumlah dan tugas aparatur pengadilan, khususnya hakim, untuk menyelesaikan tugas-tugas peradilan tersebut.

Selanjutnya, dengan berlakunya UU No. 7 tahun 1989 posisi PADI semakin kuat, dan dasar penyelenggaraannya mengacu kepada peraturan perundang-undangan yang unikatif. Berkenaan dengan hal itu, maka dalam uraian berikutnya dikemukakan tentang UU no.7 tahun 1989 serta instruksi presiden No. 1 tahun 1991 tentang penyebar luasan kompilasi hukum Islam.

Dengan keluarnya Undang-undang Nomor 14 Tahun 1970 tentang Ketentuanketentuan Pokok Kekuasaan Kehakiman, maka kedudukan Peradilan Agama mulai nampak jelas dalam sistem peradilan di Indonesia. Undang-undang ini menegaskan prinsip-prinsip sebagai berikut : Pertama, Peradilan dilakukan "Demi Keadilan Berdasarkan ketuhanan Yang Maha Esa"; Kedua, Kekuasaan kehakiman dilakukan oleh pengadilan dalam lingkungan Peradilan Umum, Peradilan Agama, Peradilan Militer dan Peradilan Tata Usaha Negara; Ketiga, Mahkamah Agung adalah Pengadilan Negara Tertinggi. Keempat, Badan-badan yang melaksanakan peradilan secara organisatoris, administratif, dan finansial ada di bawah masing-masing departemen yang bersangkutan. Kelima, susunan kekuasaan serta acara dari badan peradilan itu masing-masing diatur dalam undang-undang tersendiri. Hal ini dengan sendirinya memberikan landasan yang kokoh bagi kemandirian peradilan agama, dan memberikan status yang sama dengan peradilan-peradilan lainnya di Indonesia. 
Lahirnya Undang-Undang Nomor 1 Tahun 1974 tentang Perkawinan memperkokoh keberadaan pengadilan agama. Di dalam undang-undang ini tidak ada ketentuan yang bertentangan dengan ajaran Islam. Pasa1 2 ayat (1) undang-undang ini semakin memperteguh pelaksanaan ajaran Islam (Hukum Islam). Suasana cerah kembali mewarnai perkembangan peradilan agama di Indonesia dengan keluarnya Undang-undang Nomor 7 Tahun 1989 tentang Peradilan Agama yang telah memberikan landasan untuk mewujudkan peradilan agama yang mandiri, sederajat dan memantapkan serta mensejajarkan kedudukan peradilan agama dengan lingkungan peradilan lainnya. ${ }^{22}$

Dalam sejarah perkembangannya, personil peradilan agama sejak dulu selalu dipegang oleh para ulama yang disegani yang menjadi panutan masyarakat sekelilingnya. Pada masa kerajaan-kerajaan Islam, penghulu Keraton sebagai pemimpin keagamaan Islam di lingkungan Keraton yang membantu tugas raja di bidang keagamaan yang bersumber dari ajaran Islam, berasal dari ulama seperti Kanjeng Penghulu Tafsir Anom IV pada Kesunanan Surakarta. Ia pernah mendapat tugas untuk membuka Madrasah Mambaul Ulum pada tahun 1905. Demikian pula para personil yang telah banyak berkecimpung dalam penyelenggaraan peradilan agama adalah ulama-ulama yang disegani, seperti: $\mathrm{KH}$. Abdullah Sirad Penghulu Pakualaman, KH. Abu Amar Penghulu Purbalingga, K.H. Moh. Saubari Penghulu Tegal, K.H. Mahfudl Penghulu Kutoarjo, KH. Ichsan Penghulu Temanggung, KH. Moh. Isa Penghulu Serang, KH. Musta'in Penghulu Tuban, dan KH. Moh. Adnan Ketua Mahkamah Islam Tinggi tiga zaman (Belanda, Jepang dan RI) (Daniel S. Lev: 5-7). Namun sejak tahun 1970-an, perekrutan tenaga personil di lingkungan peradilan agama khususnya untuk tenaga hakim dan kepaniteraan mulai diambil dari alumni IAIN dan perguruan tinggi agama.

\footnotetext{
${ }^{22}$ http://www.pa-negara.go.id/tentang-kami/sejarah-singkat
} 


\section{KESIMPULAN}

Dengan berbagai ragam pengadilan itu menunjukkan posisinya yang sama sebagai salah satu pelaksana kerajaan atau sultan. Di samping itu pada dasarnya batasan wewenang agama meliputi bidang hukum keluarga, yaitu perkawinan kewarisan. dengan wewenang demikian, proses petumbuhan dan perkembangan pengadilan pada berbagai kesultanan memiliki keunikan masing-masing. Pengintegrasian, atau hidup berdampingan antara adat dan syara', merupakan penyelesaian konflik yang terjadi secara laten bahkan manifes sebagaimana terkaji di Aceh, Minangkabau, dan di beberapa tempat di Sulawesi Selatan. Kedudukan sultan sebagai penguasa tertinggi, dalam berbagai hal, berfungsi sebagai pendamai apabila terjadi perselisihan hukum. Selanjutnya Peradilan Agama pada zaman Belanda membawa misi tertentu, mulai dari misi dagang, politik bahkan sampai misi kristenisasi. Awalnya mereka tahu bahwa di tengah-tengah masyarakat Indonesia itu berlaku hukum adat yang sudah terpengaruh oleh agama Islam dan lebih condong pada unsur keagamaannya dari pada hukum adat itu sendiri. Dari uraian singkat tentang sejarah perkembangan peradilan agama tersebut di atas dapat disimpulkan bahwa peradilan agama bercita-cita untuk dapat memberikan pengayoman dan pelayanan hukum kepada masyarakat. 


\section{DAFTAR PUSTAKA}

Abdul Hamid. (2017). Perceraian Sebab Kawin Paksa (Studi Kasus di Pengadilan Agama Jember). Asy-Syariah : Jurnal Hukum Islam , 3 (1).

Ash-Shiddieqy, Teuku Muhammad Hasby,. Peradilan dan Hukum Acara Islam, cet. 2, Semarang: PT. Pustaka Rizki Putra, 2001.

Azhari, Muhammad Thahir,. Negara Hukum: Studi Tentang Prinsip-Prinsipnya Dilihat dari Segi Hukum Islam, cet. 1, Jakarta: Bulan Bintang, 1987.

Bisri, Cik Hasan. 2003. Peradilan Agama Di Indonesia. Jakarta: PT. Raja Grafindo Persada

Gunaryo, Achmad. 2006. Pergumulan Politik Dan Hukum Islam. Yogyakarta: Pustaka Pelajar.

Halim, Abdul. 2000. Peradilan Agama Dalam Politik Hukum Islam. Jakarta: PT. RajaGrafindoPersada.

http://www.pa-negara.go.id/tentang-kami/sejarah-singkat

Jalil, Basiq. 2006. Peradilan Agama di Indonesia. Jakarta: Prenada Media Group.

Juhaya S. Praja, Filsafat Hukum Islam,Bandung; LPPM Unisba, 1995.

Mertokusumo, Sudikno "Sejarah Peradilan dan Perundang-undangannya di Indonesia sejak 1942 dan apakah kemanfaatannya bagi bangsa Indonesia”, Liberty, Yogjakarta, 1983.

Tresna, R. "Peradilan di Indonesia dari Abad ke Abad”, Pradnya Paramita, Jakarta, 1977.

Wahyudi, Abdullah Tri. 2004. Peradilan Agama Di Indonesia. Yogyakarta: Pustaka Pelajar.

Wignyosubroto, Sutandyo "DARI HUKUM KOLONIAL KE HUKUM NASIONAL, Suatu Kajian tentang Dinamika Sosial Politik dalam Perkembangan Hukum Selama Satu Setengah Abad di Indonesia (1840-1990)”, PT Raja Grafindo Persada, Jakarta, 1995

Zaini Ahmad Nuh, Hakim Agama dari Masa ke Masa, cet. 1, Jakarta: Munas Ikaha, 1995. 